\title{
Primary insulin autoimmune syndrome in an Italian woman: a case report
}

\author{
Antonio Balestrieri, ${ }^{1}$ Elena Magnani, ${ }^{2}$ Cecilia Ragazzini, ${ }^{1}$ Giampiero Pasini ${ }^{2}$ \\ ${ }^{1}$ UOS Endocrinologia e Diabetologia; ${ }^{2}$ UOC Medicina Interna, Presidio Ospedaliero M. Bufalini, ASL della Romagna, Cesena \\ (FC), Italy
}

\begin{abstract}
Insulin autoimmune syndrome (IAS) is a rare syndrome characterized by fasting or postprandial hypoglycemia, high levels of anti-insulin antibodies and high concentration of total serum immunoreactive insulin. It is relatively known in Japan, rare in remaining Asia and it is extremely uncommon in Western countries, being characterized by a different race-related incidence and associated with HLADR4 alleles. Usually IAS is related to particular drugs, or to autoimmune, rheumatologic or hematological diseases, while it is very rare as a primary form. Here we described a case of an Italian woman affected by a primary form of Hirata syndrome.
\end{abstract}

\section{Introduction}

Insulin autoimmune syndrome (IAS), originally reported by Hirata in 1970, is a syndrome characterized by fasting or more frequently postprandial hypoglycemia, high levels of anti-insulin antibodies and elevated levels of total serum immunoreactive insulin. IAS usually affects adult patients with a peak age of onset in the $6^{\text {th }}$ and $7^{\text {th }}$ decade of life, in both sexes, rarely described in children. It is relatively known in Japan, rare in remaining Asia and it is extremely uncommon in Western countries, being characterized by a different race-related incidence. In particular, in Japanese and Korean ethnicities IAS is the third leading cause of spontaneous hypoglycemic attacks after insulinoma and extra pancreatic tu-

Correspondence: Antonio Balestrieri, UOS Endocrinologia e Diabetologia, Presidio Ospedaliero M. Bufalini, piazzale M. Giommi 140, 47521 Cesena (FC), Italy.

Tel.: +39.0547.394346 - Fax: +39.0547.352876.

E-mail: abalestrieri@ausl-cesena.emr.it

Key words: Hypoglycemia; insulin autoimmune syndrome; Italy.

Conflict of interest: the authors have no conflict of interest.

Received for publication: 12 February 2014.

Revision received: 16 June 2014.

Accepted for publication: 30 July 2014.

This work is licensed under a Creative Commons Attribution NonCommercial 3.0 License (CC BY-NC 3.0).

(C) Copyright A. Balestrieri et al., 2015

Licensee PAGEPress, Italy

Italian Journal of Medicine 2015; 9:169-172

doi:10.4081/itjm.2015.483 mours. Usually IAS is related to exposure to particular drugs, whereas it is less frequently associated with autoimmune, rheumatologic or hematological diseases and is very rare as a primary form. Here we described a case of an Italian woman affected by a primary form of Hirata syndrome.

\section{Case Report}

In January 2012, a 78-year-old woman was outpatient to the endocrine unit of our Hospital because of the presence of repeated episodes of tremors, weakness and tachycardia, sometimes associated with a sense of anxiety and sweats. Such episodes generally took place in the late morning and in the late afternoon. The episodes got started 4-5 months before and were becoming more intense. In two occasions the woman has been referred to the Emergency Department; in the first episode she was discharged with the diagnosis of dizziness and in the second one blood glucose of $44 \mathrm{mg} / \mathrm{dL}$ was documented. The woman had a personal past history of postural dizziness, a negative history of cancer, cardiovascular, autoimmune diseases and diabetes mellitus; she was not a smoker and usually she did not drink alcohols and did not assume any medications. Some weeks before her general practitioner prescribed atenolol for evidence of arterial hypertension and he appointed a 2-h oral glucose tolerance test, resulting in normal fasting glycemia of $88 \mathrm{mg} / \mathrm{dL}$ [normal value (n.v.) $60-100$ $\mathrm{mg} / \mathrm{dL}]$ and a glycemia of $211 \mathrm{mg} / \mathrm{dL}$ at $120 \mathrm{~min}$; dosage of glycated hemoglobin (HbA1) was $6 \%$.

At physical examination no abnormal alterations were present and her body mass index was normal $\left(21 \mathrm{~kg} / \mathrm{m}^{2}\right)$.

Endocrine tests documented a normal value of 
adrenocorticotropic hormone, cortisol and normal fasting glycemia $(92 \mathrm{mg} / \mathrm{dL})$, but they also showed abnormally high levels of insulin, equal to $1000 \mathrm{mU} / \mathrm{L}$ (n.v. $2.6-250 \mathrm{mU} / \mathrm{L}$ ) determined by a chemiluminescent enzyme immunoassay, and of the $\mathrm{C}$ peptide (3.1 nmol/L n.v. 0.37-1.47 nmol/L). Subsequently, the evaluation of anti-insulin antibodies (AIA) was performed, showing an extremely high level $(>20 \mathrm{U} / \mathrm{mL}$, positive AIA $>2.4 \mathrm{U} / \mathrm{mL}$ by RI) confirmed after plasma dilution $(>40 \mathrm{U} / \mathrm{mL})$. The high level of insulin was also confirmed by polyethylene glycol precipitation (73.2 mUI/L).
On the basis of these data the diagnosis of insulin autoimmune syndrome was postulated.

Subsequently, the woman was admitted to the hospital in order to exclude the presence of neoplasms or autoimmune diseases. Meanwhile, the therapy with atenolol was interrupted. Computed tomography scans of the abdomen and thorax were performed, showing no alterations such as pancreatic lesions and neoplasms. All hematologic and immunologic tests resulted negative (Table 1). Therefore, a fasting test in regimen of hospitalisation was performed and neither symptoms of hypoglycemia nor the evidence of hypoglycemia were

Table 1. Laboratory findings.

\begin{tabular}{|c|c|c|c|}
\hline \multicolumn{2}{|c|}{ Complete blood count and biochemical tests } & \multicolumn{2}{|l|}{ Endocrinological test } \\
\hline White cell count (n.v. 4.0-10.0) & $5450 / \mathrm{mm}^{3}$ & Fasting plasma glucose (n.v. 60-100) & $88 \mathrm{mg} / \mathrm{dL}$ \\
\hline Hemoglobin (n.v. 12-15.5) & $12.9 \mathrm{~g} / \mathrm{dL}$ & HBA1C (n.v. $<6 \%$ ) & $6.1 \%$ \\
\hline Platelet count $(140-400)$ & $176 / \mathrm{mm}^{3}$ & (n.v. $<42)$ & $43 \mathrm{mmol} / \mathrm{mol}$ \\
\hline \multirow{4}{*}{$\begin{array}{l}\text { ALT (n.v. <41) } \\
\text { AST (n.v. }<40) \\
\gamma \text { GT (n.v. 8-61) }\end{array}$} & \multirow{4}{*}{$\begin{array}{l}13 \mathrm{U} / \mathrm{L} \\
16 \mathrm{U} / \mathrm{L} \\
28 \mathrm{U} / \mathrm{L} \\
\end{array}$} & Insula pancreatic $\mathrm{Ab}$ (n.v. negative) & Negative \\
\hline & & C-peptide (n.v. 0.37-1.47) & $3.1 \mathrm{nmol} / \mathrm{L}$ \\
\hline & & Total insulin (n.v. 2.6-250) & $>1000 \mathrm{mU} / \mathrm{L}$ \\
\hline & & AIA (positive $>2.4$ ) & $>20 \mathrm{U} / \mathrm{mL}$ \\
\hline \multirow{5}{*}{$\begin{array}{l}\text { Creatinine (n.v. 0.5-1.0) } \\
\text { Uric acid (n.v. 2.4-5.7) } \\
\text { Sodium (n.v. 136-145) } \\
\text { Potassium (n.v. 3.5-5.1) } \\
\text { Calcium (n.v 8.5-10.3 ) }\end{array}$} & \multirow{5}{*}{$\begin{array}{c}0.81 \mathrm{mg} / \mathrm{dL} \\
5.6 \mathrm{mg} / \mathrm{dL} \\
139 \mathrm{mmol} / \mathrm{L} \\
4.3 \mathrm{mmol} / \mathrm{L} \\
9.0 \mathrm{mg} / \mathrm{dL}\end{array}$} & Anti-glutamic acid decarboxylase GAD (neg. <10) & $5 \mathrm{UI} / \mathrm{mL}$ \\
\hline & & TSH (n.v. 0.2-4.2) & $1.8 \mathrm{mUI} / \mathrm{L}$ \\
\hline & & Cortisol (n.v. 45-260) & $125 \mu \mathrm{g} / \mathrm{L}$ \\
\hline & & ACTH (n.v. 7.2-63.3) & $39.3 \mathrm{ng} / \mathrm{L}$ \\
\hline & & Autoimmunity & \\
\hline C-reactive protein (n.v. $<5$ ) & $2.1 \mathrm{mg} / \mathrm{L}$ & $\begin{array}{l}\text { Rheumatoid factor (n.v. }<20 \text { ) } \\
\text { ANA }\end{array}$ & $\begin{array}{r}10.2 \mathrm{kUI} / \mathrm{L} \\
\text { Negative }\end{array}$ \\
\hline \multirow[b]{2}{*}{ PT (n.v. 0.80-1.120) } & \multirow[b]{2}{*}{1.08} & DNAdsAb & Negative \\
\hline & & ENA (SS-A Ab, SS-B Ab, RNP Ab, Sc170 Ab Jo1 Ab, Cemp-B Ab) & Negative \\
\hline Total cholesterol (n.v. $<200$ ) & \multirow[t]{2}{*}{$277 \mathrm{mg} / \mathrm{dL}$} & MPO ANCA (neg. $<3.5$ ) & $<0.10 \mathrm{kUI} / \mathrm{L}$ \\
\hline & & PR3 ANCA (neg.<2.0) & $<0.10 \mathrm{kUI} / \mathrm{L}$ \\
\hline LDH (n.v. 135-214) & $190 \mathrm{U} / \mathrm{L}$ & C3 (n.v. 0.9-1.8) & $1.38 \mathrm{~g} / \mathrm{L}$ \\
\hline$\beta 2$-microglobuline (n.v. 0.8-2.2) & $2.2 \mathrm{mg} / \mathrm{L}$ & C4 (n.v. $0.10-0.40)$ & $0.32 \mathrm{~g} / \mathrm{L}$ \\
\hline Total protein (n.v. 60-80) & $71 \mathrm{~g} / \mathrm{L}$ & $\mathrm{TPO} \mathrm{Ab}$ & Negative \\
\hline Urinalysis & \multirow{2}{*}{ No alterations } & $\mathrm{TG} A \mathrm{~b}$ & Negative \\
\hline \multirow[b]{2}{*}{ Bence Jones } & & $\mathrm{TSH}$ receptor $\mathrm{Ab}$ & Negative \\
\hline & Negative & Transglutaminase IgA Ab (neg. <7) & $0.3 \mathrm{kUI} / \mathrm{L}$ \\
\hline Protein electrophoresis & Normal & EMA Ab & Negative \\
\hline
\end{tabular}

Table 2. Oral glucose tolerance test.

\begin{tabular}{lccc}
\hline $\begin{array}{l}\text { Time } \\
(\text { min) }\end{array}$ & $\begin{array}{c}\text { Glucose } \\
\text { (n.v. 60-100 mg/dL) }\end{array}$ & $\begin{array}{c}\text { Insulin } \\
\text { (n.v. 2.6-250 mU/L) }\end{array}$ & $\begin{array}{c}\text { C peptide } \\
\text { (n.v. 0.37-1.47 nmol/L) }\end{array}$ \\
\hline 0 & 93 & $>1000$ & 2.08 \\
\hline 120 & 166 & $>1000$ & 3.55 \\
\hline 240 & 36 & 917.6 & 2.93 \\
\hline
\end{tabular}

n.v., normal value. 
documented. Otherwise the following 75 -g oral glucose tolerance test (OGTT) induced a symptomatic hypoglycemia with a plasma glucose level of $40 \mathrm{mg} / \mathrm{dL}$ after 180 min lasting till 240 min (Table 2). Human leukocyte antigen (HLA) typing demonstrated the presence of HLA DRB $1 * 0407$. On the basis of such results the diagnosis of Hyrata syndrome was confirmed.

The patient started a low carbohydrate diet, oral prednisone at the dose of $25 \mathrm{mg}$ daily for two weeks, associated with $50 \mathrm{mg}$ of acarbose during breakfast and lunch, and finally she was discharged. The patient was advised to reduce the dose of prednisone by $5 \mathrm{mg}$ every 14 days till a dose of $5 \mathrm{mg}$ daily. A glucometer was given to the patient in order to measure her glycemia in the case of further episodes of hypoglycemia. Amlodipine at the dose of $5 \mathrm{mg}$ daily for her arterial hypertension was introduced.

In the follow up period, two months after discharge, the woman referred to an episode of malaise associated with tachycardia and sweats with a documented glycemia of $50 \mathrm{mg} / \mathrm{dL}$. Another episode of hypoglycemia of $58 \mathrm{mg} / \mathrm{dL}$ right before lunch, accompanied by dizziness and tachycardia, occurred after 4 months. AIA levels persisted elevated $(>20 \mathrm{U} / \mathrm{mL})$ as well as plasma insulin level $(138.2 \mathrm{mU} / \mathrm{L})$. A progressive reduction of AIA $(8.2 \mathrm{U} / \mathrm{mL})$ was documented in a follow up period of 24 months, and the woman did not complain about any episode of hypoglycemia and referred a general well-being and good-health states.

\section{Discussion and Conclusions}

The majority of the IAS cases described are secondary to drugs exposure, autoimmune diseases or both. Particularly evident is the association with Graves' disease and methimazol. A strong association between IAS and HLA classes II DR4 has been well confirmed, in particular in Japanese people. This genetic association is likely but less well documented even in East Asian non-Japanese population and in Caucasian population. ${ }^{1}$

Worldwide IAS has been related to the assumption of many drugs containing a sulfhydryl group (methimazole, carbimazole, penicillamine, captopril, penicillin, mercaptopropionyl glycine, glutathion, pyritinol, imipenem, isoniazide, idralazine and procainamide); in such forms IAS usually occurs from 4 to 6 weeks after the pharmacological assumption. Recently an increasing number of reports have referred to an association with IAS and $\alpha$ lipoic acid assumption..$^{2-4}$ Other secondary forms of IAS have been associated with autoimmune diseases as rheumatoid arthritis, systemic lupus erythematosus, polimiositis, vasculitis or with hematological diseases (multiple myeloma, monoclonal gammopathy of undetermined significance), liver disease and neoplasms. ${ }^{1,5,6}$

It is very hard to estimate the number of patients affected by IAS out of Japan reported in the Literature. Uchigata and Hirata ${ }^{1}$ have been reported only in 47 of non-Asian-IAS patients where 3 were Italian, while Lupsa et $a .^{7}$ numbered 58 cases of IAS where 2 of them were Italian.

After searching in central Pubmed and Embase for publications from 1970 to 2013, we have found 5 Italian case reports about Hirata disease, four concerning adults and one description of a child., ${ }^{4-11}$ This suggests that the incidence of IAS is extremely rare in Italy.

The case here described is one of the few documented cases of IAS in a non-Asian patient not associated with diseases or drugs and with the presence of HLA DRB $1 * 0407$ allele that confers a genetic predisposition and that is more frequent in Caucasian respect to Asian people. ${ }^{1}$

Similarly to most of the cases reported in the literature, the woman presented episodes of postprandial hypoglycemia. The mechanism of postprandial hypoglycemia remains largely unknown but it seems that insulin, secreted after a meal, bounds its antibodies and dissociates from the complex insulin/antibody in an unregulated way. As demonstrated by Dozio et al. ${ }^{8}$ because of a buffering effect of insulin antibodies, the availability of insulin in liver and peripheral tissues is changeable and can be reduced. This effect can explain the lack of a prompt hypoglycemic response and the impaired glucose tolerance or overt diabetes reported in some patients. Even in our patient a diabetic pattern at the 2-h OGTT was documented.

This case suggests that searching for anti-insulin antibodies in the evaluation of hypoglycemia in seemingly well people may be essential in the differential diagnosis of hyperinsulinism, in order to discriminate endogenous causes like insulinoma and autoimmune hyperinsulinism, ${ }^{12}$ even when no drug related or IAS related diseases are known. Besides, this case confirms that Hyrata syndrome may exist even as a primary or idiopathic disease because we did not document in the woman the onset of autoimmune diseases or other Hirata related disorders in the follow up period of 24 months as documented by other Authors in longer follow up periods. ${ }^{11,13}$

\section{References}

1. Uchigata Y, Hirata Y. Insulin autoimmune syndrome (Hirata disease). In: Eisenbarth S, ed. Immunoendocrinology: scientific and clinical aspects, contemporary endocrinology. Berlin: Springer; 2011. pp 343-67.

2. Uchigata Y, Hirata Y, Iwamoto Y. Drug-induced insuline autoimmune syndrome. Diabetes Res Clin 2009; 83:e19-20.

3. Gullo D, Evans JL,Vigneri R, et al. Insulin autoimmune syndrome (Hirata Disease) in European Caucasians taking $\alpha$-lipoic acid. Clin Endocrinol (Oxf) 2014;81:204-9.

4. Bresciani E, Bussi A, Bazzigaluppi E, Balestrieri G. In- 
sulin autoimmune syndrome induced by $\alpha$ lipoic acid in a Caucasian woman: case report. Diabetes Care 2011; 34:e146.

5. Arnqvist H, Halban PA, Mathiesen UL, et al. Hypoglycemia caused by atypical insulin antibodies in a patient with benign monoclonal gammopathy. J Intern Med 1993;234:421-7.

6. Shah P, Mares D, Fineberg E, et al. Insulin autoimmune syndrome as a cause of spontaneous hypoglycemia in alcoholic cirrhosis. Gastroenterology 1995;109:1673-6.

7. Lupsa BC, Chong AY, Gorden P, et al. Autoimmune forms of hypoglycaemia. Medicine 2009;88:141-53.

8. Dozio N, Scavini M, Sodoyez JC, et al. Imaging of the buffering effect of insulin antibodies in the autoimmune hypoglycemic syndrome. J Clin Endocrinol Metab 1998; 83:643-8.

9. Annese S, Fadini G, Maran A. Caso di ipoglicemia au- toimmune trattata con plasmaferesi. Giorn Ital Diabetol Metab 2008;28:162-4.

10. Dozio N, Sarugeri E, Pozza G, et al. Insulin receptor antibodies inhibit insulin uptake by the liver: in vivo 123I-insulin scintigraphic scanning and in vitro characterization in autoimmune hypoglycemia. J Invest Med 2001; 49:85-92.

11. Meschi F, Dozio N, Bognetti E, et al. An unusual case of recurrent hypoglycaemia: 10-year follow up of a child with insulin autoimmunity. Eur J Pediatr 1992;151:32-4.

12. Cryer P, Axelrod L, John F, et al. Evaluation and management of adult hypoglycemic disorders: an endocrine society clinical practice guideline. J Clin Endocrinol Metab 2009;94:709-28.

13. Cavaco B, Uchigata Y, Porto T, et al. Hypoglycaemia due to insulin autoimmune syndrome: report of two cases with characterization of HLA alleles and insulin autoantibodies. Eur J Endocrinol 2001;145:311-6. 